\title{
The Effect of Stakeholder Power, Board Gender Diversity and Human Capital on Environmental Disclosure with Board Independent as Moderation Variable
}

\author{
Siti Choiriah* \\ Universitas Mercu Buana, Jakarta Indonesia \\ Ria \\ Universitas Nasional, Jakarta Indonesia
}

\begin{abstract}
This study aims to determine the influence of Stakeholder Power, Board Gender Diversity and Human Capital on Environmental Disclosure and Board Independence as a moderating variable. This research is a causal research with a quantitative descriptive approach with the object of research in manufacturing companies listed on the Indonesia Stock Exchange (IDX). Research data is secondary data obtained from looking at the financial statements of companies included in manufacturing companies listed on the Stock Exchange. The variables of this study consisted of independent variables consisting of three variables, namely Stakeholder Power, Board Gender Diversity and Human Capital and Board Independence. And one dependent variable is Environmental Disclosure. Keywords: Stakeholder Power, Board Gender Diversity, Human Capital, Board Independence and Environmental Disclosure
\end{abstract}

DOI: $10.7176 /$ RJFA/11-12-04

Publication date:June 30th 2020

\section{Introduction}

Entering the Industrial 4.0 era, the world is currently experiencing a very rapid technological development, including Indonesia which is certainly affected by the rapid development of technology that is currently developing. This rapid technological development is followed by the development of several companies in Indonesia, of course. This condition is used by companies in Indonesia to bring up the latest innovations that are not only followed by old companies, but many new companies are emerging and increase competition in Indonesia to generate as much profit as possible. The company's goal in increasingly stringent and competitive economic conditions is to get maximum profits with growth in the long run and also to maintain the viability of the company itself according to Choiriah (2019a). Meanwhile, according to Nengzih (2014) Companies with good governance, management control systems and planning will have an impact on the company's survival. The growing company in Indonesia has also had a positive impact in terms of economic, environmental and social. Environmental issues cannot be avoided anymore and become something endless to discuss. As a result of the business processes carried out by the company unwittingly not only bring positive impacts but also bring negative impacts on the environment around the company. The company's operations that are not environmentally friendly can cause pollution and waste that can pollute the environment. Manufacturing companies are believed to contribute the most to environmental pollution in terms of pollution and waste itself. Many manufacturing companies stand in the midst of many densely populated houses. This is what causes many manufacturing companies to deal directly with the community resulting in production waste polluting the environment.

The problem of environmental pollution as a result of company operations can be seen in several regions in Indonesia revealed by the Inspector General of the Ministry of Environment (KLH) earlier this year. For manufacturing companies also occurred in 2017, namely paper companies on the island of Sumatra whose activities cause environmental damage by polluting water, air and soil. The people who live around the factory feel the direct impact of air pollution caused by the factory chimneys that produce air pollution which causes health problems. The absence of a company renovation from the start also caused waste seepage to leak into the walls of the sewage that polluted the water sources and rivers that were around the factory. The company is suspected of doing expansion that is not balanced with the ability and capacity of the environment, causing many environmental problems and health impacts on the surrounding community. Still remember the Lapindo mud case that occurred in several villages in Sidoarjo which until now has not been resolved, which in the end the Lapindo Brantas mudflow case was declared a natural disaster and not a drilling disaster. Then in 2015 large forest fires occurred on the islands of Kalimantan and Sumatra caused by illegal logging by paper and pulp companies without reforestation which caused some people to die due to difficulty breathing due to thick black smoke that also spread to neighboring countries, the floods that occurred due to the clogging of rivers by factory waste, landslides caused by soil balance and reduced soil fertility, even the death of some ecosystems at sea caused by continuous capture to meet production targets without the use of safe and procedural tools (Sindo, March 14, 2018). 
Human resources have long been recognized as important assets and value creators for companies and, in today's business environment, human resources are considered as the main source of competitive advantage. With a "knowledge agenda", companies see employees as important resources and invest a lot in them. Disclosure of adequate human capital information is important because it affects not only the company's ability to recruit and retain the best people, but also convey the company's potential to create value and thus its share price and ability to attract funding nationally and internationally (Huang, Luther, Tayles, Haniffa, 2013).

Gender presentations in board members also have an impact on social and environmental disclosure around the company. The term gender is used to describe characteristics between men and women. Gender diversity that occurs in companies can affect disclosure, because women and men have different backgrounds traditionally, culturally and socially. Board gender diversity has been considered an important dimension of corporate governance that can influence the level of environmental disclosure (Liao, 2014). Gender diversity in the board of directors is very important to carry out its monitoring function, because the more diverse board has a combination of capacity and experience, which is an important factor in the effectiveness of the board (Jizi, 2017). Women's participation can increase transparency in administration and monitoring, triggering greater voluntary reporting (Adams and Ferreira, 2009). According to Hillman and Dalziel (2003), diversity on the board provides a more balanced, diverse experience of the board and functions more effectively, which can increase monitoring and increase investor confidence.

The board is certainly one of the stakeholders in the company. Stakeholders are groups or individuals that can influence and or are influenced by the achievement of certain goals (Freeman, 1984). The power of stakeholders is an important factor to consider every time a company reports on the relationship between the business and its stakeholders. Stakeholder power includes the influence exerted by various stakeholder groups on the company, and these stakeholder groups are usually shareholders, creditors, the government, and special interest groups according to Cormier and Magnan (2003) and Garcia-Sanchez (2013). In making financial reports and environmental disclosure reports must be in accordance with what the stakeholders want. Stakeholders highly expect transparency, sustainability and accountability within the company. Environmental disclosure and disclosure practices must be highly considered by stakeholders because of the impact of the organization's actions on the environment.

Within a company there is usually an internal board and board independence. Internal board members in companies usually have direct responsibility for company management or perhaps family members who own the company. Whereas for board independence they usually only represent the interests of shareholders and are not directly involved in the activities of their companies, their cooperative relations with the company are only merely directorships (Rouf, 2011). Board independence can help companies to monitor and control the company's management externally

In a previous study of the influence of stakeholder power by Weihena, Kawshala and Shamil (2017) stated that the strength of creditors has a significant relationship with the disclosure of the company's environment while the strength of shareholders and the power of the government is not significantly related to the disclosure of the company's environment. However, this is not in line with Hartanto \& Purwatiningsih's (2014) study which concluded that Shareholder power, firm size, and profitability have a positive influence on social and environmental disclosure while government power and creditor power have no significant effect on social and environmental disclosure. According to $\mathrm{Lu} \&$ Abeysekera (2014) which states that the role of various strong stakeholders in influencing corporate social and environmental disclosure is found to be very weak in China, but this is different from environmental disclosure.

According to previous research from Allipour, Ghanbari, Jamshidinavid, and Taherabadi (2019) states that board independence has a significant positive effect on environmental disclosure. Meanwhile, Akbas (2016) states in his research that board independence does not have an effect on environmental disclosure. Said, Omar, and Abdullah (2012) stated that there was a significant relationship between board independence, business characteristics, and human capital especially in age and sex. Another research on the influence of board gender diversity by Manita (2018) which states that no significant relationship was found between board gender diversity and ESG disclosure. However, it is different from Fortunella \& Hadiprajitno (2015) and Omar \& Said (2012) which states that the proportion of women on the board has a significant relationship with environmental disclosure. Similarly, Kathyayini (2012) and Solikhah \& Winarsih (2016) found a positive relationship between women councilors and the quality of environmental reporting.

\section{Theory Review, Hypothesis Development}

\subsection{Theory Review}

2.1.1 Stakeholder Theory

Stakeholders are all parties, both internal and external who have a relationship that is both influential and influenced, directly or indirectly by the company. Thus, stakeholders are internal and external parties, such as: government, competing companies, surrounding communities, the international environment, institutions outside 
the company (NGOs and the like), environmental watchdogs for company workers, minorities and others whose existence greatly influences and influenced by companies (Nor Hadi, 2011: 93) According to Lu and Abeysekera (2014) stakeholder theory tries to explain how companies identify powerful stakeholder groups that can influence, or are influenced by, social and environmental disclosure practices of companies, and how companies respond their hopes. Agency theory assumes that companies need support from stakeholders in managing their company. Because stakeholders take part in the company's decision making and require stakeholder approval.

According to stakeholder theory, companies usually use Corporate Environmental Reporting (CER) and Corporate Social Responsibility (CSR) to reduce the problem of conflict between management and stakeholders. CER and CSR are considered as communication tools between management and stakeholders according to Alipour et al (2019).

\subsubsection{Legitimacy Theory}

Legitimacy is a psychological state of partiality of people and groups of people who are very sensitive to the symptoms of the surrounding environment both physical and non-physical (Nor Hadi, 2011: 87). The legitimacy theory states that organizations continually look for ways to ensure their operations are within the limits and norms prevailing in society (Rokhlinasari, 2018). This theory of legitimacy is related to the 'social contract' between the community and the operating company. Where the community has special standards for companies that operate around their neighborhood. This social contract is not always permanent, but it changes along with the development of a company and the surrounding environment. This can be a motivation or vice versa as the company's pressure to face changes and adapt them to the company's products, methods and goals (Nor Hadi, 2011: 88).

\subsubsection{Stakeholder Power}

According to ISO 26000 Stakeholders are defined as individuals or groups who have an interest in the decisions and activities of the organization and groups that can influence and / or be affected by activities, products or services, and organizational performance.

Stakeholders means individuals or groups from internal or external parties who have an interest in the business strategy of the organization. Those included in the stakeholders include employees, managers, board of directors, shareholders, customers, suppliers, government and local communities where the organization operates.

The following are the stakeholders who are directly related to the company's business. The owner of the shares is initially the only owner of the company who establishes and runs and develops his business idea, but because the business requires no small amount of funds, the owner invites investors to invest in his company as additional funds. Creditors. Creditors are generally known as money supply institutions or commonly called banks, where they will provide funds for companies that need money loans. Employees, Employees together with managers play an important role in company performance and important company decisions. Managers are responsible for managing employees. Supplier (supplier) Every company needs raw materials for the production process. For this reason, the role of suppliers is needed by the company to complete its production. Consumers, Consumers have a very important role in the survival of the company in the world of competition. For companies to be able to attract consumers as good as possible by producing products in accordance with the expectations of consumers. And also the company must have its own strategy in retaining customers.

Each company has a different stakeholder group and varies in terms of number, size, influence and importance level (Pearce \& Robinson, 2013: 52). Not all stakeholders have the same level of influence on a company. Based on the priorities of which stakeholders have power or most in a company, Pearce \& Robinson (2013: 52) mentions the sequence of stakeholders the most important sequence based on a study of 2,361 commissioners from 291 large companies in the southeastern United States. The first place is occupied by customers and the government, then shareholders, employees and finally the public. Meanwhile, according to research Lu \& Abeysekara (2014) describes stakeholders who have the power of the government, shareholders, creditors and auditors.

\subsubsection{Shareholder Power}

Shareholder is one part of internal party stakeholders. Shareholders or shareholders expect the wealth they entrust to the company can be maintained and increased. There are so many perceptions that shareholders are company owners, so as much as possible the company must meet the interests of shareholders. In the company, the owners of capital that can be called as shareholders are very concerned about their willingness to determine how the company going forward. Especially the majority shareholders, who will definitely take precedence over their votes.

Supramono (2014) states that shares are identical to capital and companies in the form of Limited Liability Companies (PT). PT as a business person requires a lot of capital and its capital is divided into a number of shares. Kuswiratmo (2016) classifies the majority shareholders based on the composition of the number of shares and the rights they have. The majority shareholder is a shareholder in which the number of shares is higher than the other shareholders. The existence of a majority shareholder affects the running of a company and in terms of the 
economy can be seen who is the largest investor in the company, then it is suitable to lead the company. Or can also be called the majority shareholder is a shareholder whose shares are more than $50 \%$. With the existence of majority shares, the demands on shareholders will be increasingly concentrated.

\subsubsection{Board Gender Diversity}

In recent years, board gender diversity has become an important component of corporate governance structures throughout the world. Board gender diversity is the gender diversity found on the board of directors. The board is one of the main mechanisms of corporate governance and its characteristics can influence the level of environmental disclosure. Gender diversity is also one of the characteristics of the board of directors. Four board characteristics, namely board size, board independence, board gender diversity and audit committee independence. Gender diversity in the board of directors is very important to carry out its monitoring function, because the more diverse board has a combination of capacity and experience, which is an important factor in the effectiveness of the board (Jizi, 2017). Differences in background, active involvement of women directors, independence and other factors enable women directors to contribute to more complex discussions and decisions such as environmental disclosure.

Indonesia companies have now given the opportunity for every individual to occupy all positions, as seen from the presence of a women's council in the company (Hadya \& Susanto, 2018). Because it is considered that this era the position of women is equal to men. The role of women is also highly considered in the company, because basically women's performance is more thorough than the performance of men.

\subsubsection{Human Capital}

Literally the notion of human capital is knowledge (knowledge), expertise (expertise), ability (ability) and skills (skills) that make humans as capital or assets of a nation (Sagala, 2017: 37). Human capital is not an inherent thing in a company. But it is usually the people who work at the company that bring the value of human capital into the company. Not only that, this next human capital is developed in company training that is useful for maintaining human capital as a corporate investment. Not only maintaining this can also develop in order to produce even better afterwards. Employees certainly expect rewards that are commensurate with what they have done, including increased income and guaranteed work safety. As for the company itself, they will want an increase in employee skills and competencies, performance and productivity.

The theory of human capital focuses attention on resources, human resource development, and strategies for rewarding practices. With the existence of human capital led to the theory that employees are considered as assets of the company and investment in human resources is believed to give the appropriate results to the company. Human capital is one of the most important elements of an organization's intangible assets. These intangible assets, especially the expertise, imagination, and creativity of employees, are vital for achieving organizational success. The importance of human assets causes the importance of measuring the value of intangible assets. Measurement is a means to assess how well the use and effectiveness of human capital management is. (Baron, Armstrong, 2013; 3). Research by Ewert and Baker (2001), Cottrel (2003), Kollmus and Agyman (2002) states that there is a relationship between age, sex, income, education and academics on environmental activities and demographic background characteristics. According to research by Rivera and De Leon (2005), the level of formal education and environmental care of the board of directors is significantly related to the company's participation in social and environmental activities. Whereas Ewert and Baker (2001) stated that the board of directors with a background in financial and legal education has more to do with social and environmental activities because many report in annual reports.

\subsubsection{Board Independence}

The board of directors is one of the important and beneficial internal corporate governance that can protect the interests of shareholders. The board of directors themselves have direct responsibility to the company to prepare and carry out strategies for the company's sustainability ( $\mathrm{Wu}, \mathrm{Li}, 2015)$. The board of directors generally consists of a dependent board and board independence (Akbas, 2016). Board independence refers to the structural composition of the board with respect to the presence of insiders vs. outsiders. Outside board members are those who currently do not work or have never worked for a company and do not have family relations with the executive. In contrast, board members in either currently holding or have held positions in the company (Muller-Kahle et al, 2014). Directors hold positions where they can provide important information about company operations. They also have an incentive to hide sensitive information related to poor company performance and non-compliance with statutory laws to secure their work at the expense of the interests of shareholders (Virk, 2017). Many national governance codes have suggested that boards must have a majority of outside directors to maintain independence from management (Muller-Kahle, Wang, Wu, 2014). Board independence tends to be more socially aware and responsive to the needs of various stakeholders. Board independence can provide a variety of inputs into strategic decision making to promote broader stakeholder orientation (Dunn, Sainty, 2009). In the face of conflict between 
controlling shareholders and minority shareholders, board independence can more or less protect minority shareholders so that their wealth is not taken over (Khosa, 2017).

\subsubsection{Environmental Disclosure}

The concern of the company both internal and external at this time led to speculation that revealing what happened in the company environment is considered important. Environmental disclosure is a systematic statement describing the company's environmental burden and environmental efforts including corporate objectives, environmental policies, activities and environmental impacts, reported and published periodically to the public (Ong $\mathrm{t}$ al, 2016). Environmental disclosure explains whether the company's activities will have an impact on the environment (Said, Omar, Abdullah, 2013). This makes Environmental disclosure a form of corporate social responsibility, where through annual reports, the public, investors and companies make Environmental disclosure as a means of communication and decision making in seeing the company's environmental activities (Paramitha, Rohman, 2016).

Companies registered in industries related to heavy pollution must disclose environmental information regularly, issue annual environmental reports and encourage companies registered in other fields to apply with reference to the results disclosed. Complete and comprehensive disclosure of environmental information is at the core of environmental protection, so the preparation and disclosure of environmental information in listed companies is very important to help creditors, investors, the public and government administration in learning about the company's environmental protection situation (Wang, Zhang, 2019).

Environmental reports in annual reporting in Indonesia are still voluntary rather than mandatory. The law that requires the reporting of environmental impacts is contained in the Decree of the Minister of Environment No. 17 of 2001 concerning Types of Business Plans and / or Activities that Must Be Completed with an Analysis of Environmental Impacts. And also regulated in Law No. 23 of 1997 concerning Environmental Management (Rahmawati, Subardjo, 2017). Indonesia has also created environmental programs in Indonesia including: Environmental Impact Assessment (AMDAL), Clean River Program (PROKASIH), Hazardous and Toxic Waste Management (B3), ADIPURA, Cleaner Production, Environmental Performance Assessment Program (PROPER), etc. (Ikhsan, 2009: 8).

\subsection{Hypothesis Development}

2.2.1 Effect of Shareholder Power on Environmental Disclosure

In a company, of course, there are shareholders whose shares are the largest among the other shareholders called majority shareholders. The existence of shareholders is an influence for the company going forward. With the majority shareholders, the focus of demands on the shareholders will be more concentrated.

In a previous study by Lu \& Abeysekara (2014) which proxied the presentation of majority share ownership as a representation of shareholder power proved that shareholder power significantly affected environmental disclosure. In line with Hartanto \& Purwatingsih (2014) which also proxies shareholders with majority share ownership and also results in research that shareholder power significantly influences social and environmental disclosure. In line with the research above Lu \& Abeysekera (2014) states that shareholders have influenced the company's disclosure in relation to the company's environmental performance

Subsequent research by Weihena K.N (2017) which also proved that the role of several influential stakeholders in encouraging corporate social and environmental disclosure is usually weak in China. Based on the above research it can be concluded that the hypothesis:

H1: Shareholder Power has a positive effect on environmental disclosure

\subsubsection{Effect of Board Gender Diversity on Environmental Disclosure}

The diversity in the board of directors is often associated with environmental disclosure, one of which is often debated is the diversity of the board's gender. Between women and men socially, traditionally and culturally different. This difference can also be characterized by personality, lifestyle, leadership style, communication style and also the way of working between men and women.

In a previous study by Kathyayini (2012) found a positive relationship between the proportion of women on the board and environmental disclosure, the same as research conducted by Omar \& Said (2015) which concluded that there is a relationship between women on the board and environmental disclosure in line with research by Winarsih and Solikhah (2015) who stated that gender diversity in the council had a positive influence on the quality of environmental disclosure. From the whole description above, the following hypotheses can be made:

H2: Board gender diversity has a positive effect on Environmental Disclosure

\subsubsection{Effect of Human Capital on Environmental Disclosure}

The concept of human capital initiates the added value that employees (humans) can give to the organization where they work (Baron \& Armstrong, 2013). Fixing human capital is to direct human resources to become qualified, 
dignified, superior and characterized human beings (Sagala, 2017). Ewert and Baker's research (2001) states that boards of directors with a background in financial and legal education have more to do with social and environmental activities because many report in annual reports. Meanwhile, according to Said, Omar, Abdullah (2013) found that human capital with age, gender and knowledge background backgrounds found a significant relationship for the chairman's age and CEO with law background. Whereas for CEO's age, the proportion of female directors, a chairman / CEO with a finance background there is no significant relationship. The hypotheses that can be put forward are as follows:

H3: Human capital has a positive effect on Environmental Disclosure

\subsubsection{Board independence as a moderating variable}

Board independence within a company functions as someone who controls and monitors the company's operations in terms of its relationship that is not directly tied to the company (Agyei-Mensah, 2016). According to agency theory, board independence is very influential in environmental disclosure in companies. $\mathrm{Wu}, \mathrm{Li}(2015)$ found that increasing the number of board independence at companies would reduce the chance of fraudulent transactions at the company. According to Lim et al (2007) Board independence has a positive influence on Environmental Disclosure. Similarly, according to Khaty Rao et al (2012) and Wall et al (2012) stated that board independence has a positive influence on environmental problems. According to Stern et al (1993) and Jaffe and Hype (2000) states that women are more aware and concerned about the environment and personal well-being. According to Ewert and Baker (2001) states that boards of directors with financial and legal backgrounds are more concerned with the environment because they report it in the annual report. Then the hypotheses that can be put forward are: H4: Shareholder Power has a positive effect on Environmental Disclosure which is moderated by the Board of Independence

H5: Board Gender Diversity has a positive effect on Environmental Disclosure which is moderated by the Board of Independence

H6: Human Capital has a positive effect on Environmental Disclosure which is moderated by the Board of Independence

\section{Research Methods}

The form of this research is causal. Causal research aims to test the hypothesis about the effect of one or several variables (independent variables) on other variables (the dependent variable). Namely by analyzing and explaining the effect of independent variables on the dependent variable. This study examines the effect of Stakeholder Pressure, Board Gender Diversity, Human capital and Board Independence on Environmental Disclosure. The independent variables in this study are Stakeholder Power, Board Gender Diversity Human Capital and Board Independence, and the dependent variable is Environmental Disclosure, where the variables have an influence on each other.

The population in this study are manufacturing companies listed on the Indonesia Stock Exchange (IDX) in 2016-2018. The sample in this study used a purposive sampling method, which is a sampling method that is in line with the objectives of this study. After determining the criteria needed, then selecting the population in accordance with the criteria.

\subsection{Method of collecting data}

This study uses secondary data types, namely data obtained through existing sources and do not need to be collected by the researcher themselves. The data used are data made by the company including annual financial reports, annual reports and sustainability reports. Data obtained from other parties includes, company websites and other sites related to research. The method of data collection is the technique of financial statement documentation and annual report which can be downloaded at the Indonesia Stock Exchange (www.idx.co.id) and each company website.

\subsection{Definition of Variable Operations}

The research variable is something that is determined but based on the theory and confirmed by a hypothesis. The variables used in this study are the dependent and independent variables. Here the dependent variable is the Environmental Disclosure which is measured by means of content analysis of GRI Standard items by counting the disclosure items made by the company. Shareholder Power is measured by looking at the percentage of majority share ownership. Gender Diversity Board is measured by the number of female board of directors in the company. Human Capital is carried out in a dummy manner if the company has a CEO with a financial, business and management background valued at 1 and vice versa. Whereas Board Independence is the number of independent directors compared to the number of directors in the company. 


\section{Results and Discussion}

\subsection{Result}

Based on the results of data processing it can be seen that:

The sample consisted of manufacturing and mining companies listed on the Indonesia Stock Exchange (BEI) for 3 years and also fulfilled environmental disclosure (ENDC) variables, shareholder power (OWN), board gender diversity (GEND), CEO with financial background (CFINBG), and board independence (BIND). Environmental Disclosure (ENDC) has the lowest value (minimum) of 12.50 which for 3 years in a row, this value indicates that in that year the company was considered to have less social responsibility. The largest value (maximum) of 100.00 is owned by the automated companies in 2017 and 2018, this value indicates that the company has full social responsibility to the surrounding environment (see table 1). The average value (mean) of 46.3084 which shows that manufacturing and mining companies are considered to have enough social responsibility to the environment around them. And for the standard deviation of 22,12969. Shareholder Power (Own) has a minimum value owned by large pharmaceutical companies in 2016 with a value of 10.17 . And the maximum value is owned by the ceramics company for 3 consecutive years with a value of 96.31 which means majority share ownership can control the company's environmental disclosure. OWN has an average value of 55.1382 and a standard deviation of 24.42006

Table 1

Descriptive Statistics

\begin{tabular}{|l|r|r|r|r|r|}
\hline & \multicolumn{1}{|c|}{ N } & Minimum & Maximum & Mean & Std. Deviation \\
\hline ENDC & 114 & 12,50 & 100,00 & 46,3084 & 22,12969 \\
\hline OWN & 114 & 10,17 & 96,31 & 55,1382 & 24,42006 \\
\hline GEND & 114 & 4,35 & 68,00 & 17,0331 & 8,70772 \\
\hline CFINBG & 114 & 0 & 1 &, 60 &, 493 \\
\hline BIND & 114 & 6,67 & 50,00 & 25,6020 & 7,08593 \\
\hline Valid N (listwise) & 114 & & & & \\
\hline
\end{tabular}

Source: Outpus SPSS

GEND (board gender diversity) has a minimum value owned by large automotive companies in Indonesia in 2016 with a value of 4.35 while the maximum value is owned by a government-owned pharmaceutical company in 2018 with a value of 68.00 which also has an average value of 17, 0331 with a standard deviation of 8.70772. Board Independence (BIND) has the lowest value (minimum) which is 6.67 owned by ceramics companies in 2017 , this value indicates that the company is still lacking in maintaining the independence of management within the company. The biggest value (maximum) of 50.00, one of which is owned by a paper mill owned by the government for 3 years in a row, this value is considered to indicate that the company is maintaining the company's independence by presenting a number of independence boards. The average value (mean) is 25.6020. And for the standard deviation of 7.08593

\subsection{Findings and Discussion}

Table 2

Test Results Coefficient

\begin{tabular}{|l|c|c|c|c|}
\hline \multicolumn{1}{|c|}{ VARIABEL } & $+/-$ & B & t & Sig \\
\hline OWN & + & 0,173 & 2,058 & $.042 * *$ \\
\hline GEND & + & 0,858 & 3,039 & $.0,03 * *$ \\
\hline CFINBG & - &,- 105 & $-0,025$ & .980 \\
\hline OWN * BIND & - &,- 262 &,- 689 & 0,493 \\
\hline GEND * BIND & + &, 181 & 0,145 & 0.858 \\
\hline CFINBG * BIND & + & 43,073 &, 115 & $0,032 * *$ \\
\hline
\end{tabular}

Based on statistical testing and the significance of the test results can be seen in the table 2 above. From the $\mathrm{t}$ statistical test between each independent variable to the dependent variable can be explained as follows:

Hypothesis test results known shareholder power $(\mathrm{OWN}) \mathrm{t}$ value of 2.058 and the value of the variable probability of shareholder power (OWN) that is equal to 0.042 or smaller than $\alpha=0.05$ shareholder power $(\mathrm{OWN})$ effect on environmental disclosure (ENDC).

Hypothesis test results revealed that the board gender diversity (GEND) $t$ value was 3.039 and the probability value of the variable board gender diversity (GEND) was 0.003 or smaller than $\alpha=0.05$ which means board gender diversity (GEND) had an effect on environmental disclosure (ENDC).

Hypothesis test results above can be known the value of t count CEO with financial background (CEOFINBG) of -0.025 and the value of the variable CEO with financial background (CEOFINBG) that is equal to 0.980 or greater than $\alpha=0.05$ so it can be concluded that the third hypothesis is rejected which it means that the CEO with 
financial background (CEOFINBG) has no effect on environmental disclosure (ENDC).

While Board Independence as a moderating variable strengthens the relationship of the CEO of Financial Background to Environmental Disclosure, this can be seen from the significance value of 0.032 less than 0.05 . Whereas Board independence towards Shareholder power is 0.493 and Board Independence against Board Gender is 0.325 greater than 0.05 , both of which are greater than 0.05, which means that Board Independence does not strengthen Shareholder power and Board Gender.

\section{Conclusion}

The discussion in this study uses the dependent variable namely environmental disclosure and 3 independent variables consisting of shareholder power, board gender diversity, CEO with financial background. The results of testing the hypotheses that have been carried out can be summarized in the following table:

Shareholder Power has a positive effect on environmental disclosure. Shareholders expect companies to maintain and increase the wealth they have entrusted to the company. Because so many arguments that say if the shareholders are the true owners of a company. Therefore, the interests of the company should be prioritized. The shareholders are very concerned about their will to determine where the company is going. Which means the shareholder with the most portion is the controller of a company. The greater the ownership of shareholders, the more control over the company and of course in the case of environmental disclosure reports. Under-concentrated share ownership encourages management to disclose relevant information to meet the demands of shareholders (Lu \& Abeysekara, 2014). The results of this study are in line with research conducted by Lu \& Abeysekara (2014), Purwanto \& Purwatiningsih (2014) and Weihena, Kashwala \& Kamil (2017) find that shareholders influence the company's environmental disclosure.

Board gender diversity influences environmental disclosure. Based on nature theory, women and men are born with different genetics so that they have different natures and traits that ultimately affect their thought patterns and actions. Because of course between women and men socially, traditionally and culturally are different. This difference can also be characterized by personality, lifestyle, leadership style, communication style and also the way of working between men and women. With the women in the board of directors and directors aligned, the company is seen as able to provide equal opportunities for everyone to improve the value and quality of the company. Because the board of directors with female gender is considered to be more inclined towards innovation and environmental and social responsibility around them which certainly can bring positive value both financially and non-financially. The women's council also has a more conscientious attitude, and is very averse of the risks which of course also carry a positive value for the sustainability of the company. The results of this study are in line with research conducted by Kathyayini (2012) and Omar \& Said (2012) which states that board gender diversity has a positive effect on environmental disclosure. But it is not in line with the research of Riadh \& Bruna (2018), Akbas (2016) and Alazzani (2017) which states that board gender diversity does not affect the environmental disclosure of a company.

CEO with Financial Background has no effect on Environmental Disclosure. CEO with financial background as one indicator of human capital to measure the ability of human resources that focus on a particular field of expertise possessed by a person viewed from his background, namely finance or as a whole in the field of economics \& business is considered to be able to manage the company well. Thus it can be concluded that CEO with financial background has no effect on environmental disclosure. So the third hypothesis is rejected. Education in the economic field will only emphasize achievement financially, so it will not pay too much attention to the social performance that must be done by the company. So a company led by the president who has an educational background in the economic field will have a low value of environmental disclosure, because social performance is carried out only slightly. With a CEO in a company that has a background in accordance with the type of business will be increasingly needed and better able to manage their business better. The results of this study are in line with research conducted by Said, Omar and Abdullah (2012) which states that there is no influence of CEO with financial background on environmental disclosure. But not in line with research conducted by Ewert and Baker (2001) which states the influence of CEO with financial background on environmental disclosure.

\section{Acknowledgment}

This study support by the Faculty of Economics and Business and Research Center of Universitas Mercu Buana Jakarta. I'm grateful for the supported from Dean, Rector Research Center team and especially the respondent in this study.

\section{Reference}

Abdulsamad, A., Ahmed, H., \& Yaseen, A. 2017. Impact of gender diversity on social and environmental performance: evidence from Malaysia. Corporate Governance: The International Journal of Business in Society, Vol. 17 Issue: 2, pp. 266-283

Adams, R. dan Ferreira, D. (2009). Women in the Boardroom and Their Impact on Governance and Performance. 
Journal of Financial Economics, Vol. 94 No.2, pp. 291-309.

Adrianus, Hartanto dan Purwatiningsih. 2014. Pengaruh Stakeholders Power dan Karakteristik Perusahaan Terhadap Pengungkapan Sosial dan Lingkungan. Jurnal Fakultas Ekonomi Universitas Indonesia. Depok.

Akbas, H.E. (2016). Relationship between boards characteristics and environmental disclosure: Evidence from Turkish listed companies. South East European Journal of Economics and Business, Vol 11, No.2.

Alipour, M., Ghanbari, M., Jamshidinavid, B., \& Taherabadi, A. (2019). Does board independence moderate the relationship between environmental disclosure quality and performance? Evidence from static and dynamic panel data. Corporate Governance: The International Journal of Business in Society,Vol. 19, No. 3.

Baron, A., \& Armstrong, M. (2013). Human Capital Management: Konsep dan Implementasi. Jakarta; Penerbit PPM.

Choiriah. (2019.a). Effect Of Internal Audit, Supply Chain Management, And Knowledge Management On Total Quality Management, International Journal Of Economics,Business and Management Research, 3 (6);7-14

Choo Huang, C., Luther, R., Tayles, M., \& Haniffa, R. (2013). Human capital disclosures in developing countries: figureheads and value creators. Journal of Applied Accounting Research, Vol.14, No.2, 180-196.

Cormier, D., Magnan, M. (2013). Environmental Reporting Management: A Continental European Perspective. Journal Of Accounting and Public Policy, Vol. 22 No. 1. pp. 43-62.

Dunn, P., \& Sainty, B. (2009). The relationship among board of director characteristics, corporate social performance and corporate financial performance. International Journal of Managerial Finance, Vol.5, No.4, pp 407-423.

Ewert, A., \& Baker, D. (2001). Standing for Where You Sit: An Exploratory Analysis of the Relationship between Academic Major and Environment Beliefs. Environment and Behavior, SAGE Journals. Vol.33, No.5, 687707.

Fortunella \& Hadiprajitno. (2015). The Effect of Good Corporate Governance Structure and Firm Characterstic Towards Environmental Disclosure. Journal of Accounting, Vol. 4 No. 2. ISSN 2337-3806. Universitas Diponegoro.

Freeman R, E., (1984). Strategic Management : A Stakeholder Approach, Boston, Pitman.

Garcia-Sanchez, e. a. (2013). Deteriminants of Corporate Social Disclosure in Spanish Local Government. Journal of Cleaner Production, No. 39, Hal. 60-72.

Gundeep, Kaur Virk. (2017). The influence of board characteristics on corporate illegality. Journal of Financial Regulation and Compliance, Vol.25, No.2.

Hadi, Nor. (2014). Corporate Social Responsibility. Yogyakarta; Graha Ilmu.

Hillman, A. J., \& Dalziel, T. (2003). Board of Directors and Firm Performance: Integrating Agency and Resource Dependence Perspectives. Academy of Management review, Vol. 28, No. 3, pp. 383-396.

Ikhsan, Arfan. (2009). Akuntansi Manajemen Lingkungan. Yogyakarta; Graha Ilmu.

Jalal. 2008. Pembangunan Berkelanjutan, CSR dan ISO 26000. Bogor.

Jizi, Mohammad Issam, Aly Salama, Robert Dixon, Rebecca Stratling. (2014). Corporate Governance and Corporate Social Responsibility Disclosure: Evidence from the US Banking Sector. Journal of Business Ethics, Vol. 135, No. 4, pp. 615-601.

Kathyayini. (2012). Corporate governance and environmental reporting: an Australian study. The International Journal of Business Society, Vol. 12 Issue.2 pp. 143-163.

Khosa, Amrinder. (2017). Independent directors and firm value of group-affiliated firms. International Journal of Accounting \& Information Management, Vol.25 No.2.

Kuswiratmo, Bonifasius Aji. (2016). Keuntungan \& Risiko Menjadi Direktur, Komisaris, dan Pemegang Saham. Cetakan Pertama. Jakarta: PT Visimedia Pustaka

Liao, Gaoliang., Xinjun, Wang. (2014). Numerical Comparison of Thermal Performance of In-Line Pin-Fins In a Wedge Duct With Three Kinds of Coolant. Institute of Turbomachinery. Xi'an Jiaotong University. China.

Lu, Y. \& Abeysekera, I. (2014). Stakeholders' power, corporate characteristics, and social and environmental disclosure: evidence from China. Journal of Cleaner Production,Vol. 64, No. 1, Hal. 426-436.

Manita, R., Maria G.B., Rey, D., \& L'Hocine. (2018). Board gender diversity and ESG disclosure: Evidence from the US, Journal of Applied Accounting Research.

Muller-Kahle, M. I., Wang, L., \& Wu, J. (2014). Board structure: an empirical study of firms in Anglo-American governance environments. Managerial Finance, Vol.40, No.7, pp 681-699.

Nengzih. (2014). Corporate Governance, Internal Control And Voluntary Disclosures Of Environmental Accounting To Company Performance : Evidence From Hospital Industries In Indonesia, Research Journal of Finance and Accounting.5(22): 134-145

Ong, T. S., Tho, S. H., Goh, H. H., Thai, S. B., \& The, B. H. (2016). The Relationship Betweem Environmental Disclosures and Financial Perfomance of Public Listed Companies in Malaysia. International Business Management, Vol.10, No.4, pp 461-467.

Paramita, B. W., \& Rohman, A. (2004). Pengaruh Karakteristik Perusahaan Terhadap Enviromental Disclosure. 
Diponegoro Journal Of Accounting, Vol.3, No.3, pp 1-10.

Pearce II, John A. dan Robinson, Richard B, (2013). Manajemen Strategis: Formulasi, Implementasi, dan Pengendalian. Jakarta: Salemba Empat.

Rahmawati, M. I., \& Subardjo, Anang. (2017). Pengaruh Pengungkapan Lingkungan dan Kinerja Lingkungan terhadap Kinerja Ekonomi yang Dimoderasi Good Corporate Governance. Jurnal Buletin Studi Ekonomi, Vol.22, No.2, pp 200-226.

Rokhlinasari, Sri. (2016). Teori -Teori dalam Pengungkapan Informasi Corporate Social Responbility Perbankan. Al-Amwal: Jurnal Ekonomi dan Perbankan Syari'ah. Vol. 7, No. 1.

Rouf, Abdur. (2011). Corporate characteristics, governance attributes and the extent of voluntary disclosure in Bangladesh. African Journal of Business Management, Vol.5, No.19, pp 7836-7845.

Sagala, H. S. (2017). Human Capital Membangun Modal Sumber Daya Manusia Berkarakter Unggul Melalui Pendidikan Berkualitas. Depok; Kencana.

Said, R \& Omar, N. (2012). Empirical Investigations on Boards, Business Characteristics, Human capital and Environmental Reporting. Social Responsibilty Journal, Vol. 9 No. 4 2013, pp. 534-553. ISSN 1747-1117.

Solikhah, B \& Winarsih, A.M. (2016). Pengaruh Media, Sensitivitas Industri, dan Struktur Corporate Governance terhadap Kualitas Environmental Disclosure. Jurnal Akuntansi dan Keuangan Indonesia, Vol. 16 No. 1. Universitas Negeri Semarang.

Subramanyam dan John J. Wild. (2012). Analisis Laporan Keuangan. Jakarta: Salemba Empat.

Supramono, Gatot. (2014). “Transaksi Bisnis Saham dan Penyelesaian Sengketa Melalui Pengadilan”. Edisi Pertama. Jakarta: Kencana Prenadamedia Group.

Wang, J., \& Zhang, B. (2019). Quality of environmental information disclosure and enterprise characteristics: Based on heavily polluted industries of A-share in the Shanghai Stock Exchange, Management of Environmental Quality: An International Journal, Vol. 30 No. 5.

Weihena, K.N , Kawshala, B.A.H and Shamil, M.M.M. (2017). Relationship between Stakeholder Power and Corporate Environmental Disclosures: Evidence from Listed firms in Sri Lanka. International Conference on Business and Information. Conference Paper.

Wu, X., \& Li, H. (2015). Board independence and the quality of board monitoring: evidence from China. International Journal of Managerial Finance, Vol.11, No.3, pp 308-328. 